Established as an autonomous corporation by an act of the Parliament of the Republic of Singapore in May 1968, the Institute of Southeast Asian Studies is a regional research center for scholars and other specialists concerned with modern Southeast Asia. The Institute's research interest is focused on the many-faceted problems of development and social change in Southeast Asia.

The Institute is governed by a twenty-four-member Board of Trustees comprising representatives from the University of Singapore and Nanyang University, appointees from the Government, as well as representatives from a broad range of professional and civic organizations and groups. A ten-man Executive Committee oversees day-to-day operations; it is ex officio chaired by the Director, the

Institute's chief academic and administrative officer.

Institute of Southeast Asian Studies

Heng Mui Keng Terrace

Pasir Panjang

Singapore 0511 
NEW FOUNDATIONS

FOR ASIAN AND PACIFIC SECURITY 


\title{
NEW FOUNDATIONS
}

FOR ASIAN AND PACIFIC SECURITY

Based on the Addresses, Papers, Reports, and Discussion Sessions of an International Conference Held at Pattaya, Thailand, December 12-16, 1979

\author{
Edited by \\ Joyce E. Larson
}

\author{
Published by \\ Institute of Southeast Asian Studies \\ Singapore \\ in cooperation with
}

National Strategy Information Center, Inc.

New York 
New Foundations for Asian and Pacific Security

Copyright (C) 1980 by National Strategy Information Center, Inc. 171 East 58th Street New York, N.Y. 10022

No part of this publication may be reproduced, stored in a retrieval system, or transmitted in any form or by any means, electronic, mechanical, photocopying, recording, or otherwise, without the prior written permission of the publisher.

Library Edition: ISBN 0-87855-413-0

Paperbound Edition: ISBN 0-87855-845-2

LC 80-82521

Printed in the United States of America 